\title{
Successful outcome of disseminated mucormycosis in a 3-year-old child suffering from acute leukaemia: the role of isavuconazole? A case report
}

\author{
Marjorie Cornu ${ }^{1 \dagger}$, Bénédicte Bruno ${ }^{2 \dagger}$, Séverine Loridant ${ }^{1}$, Pauline Navarin ${ }^{2}$, Nadine François ${ }^{1}$, Fanny Lanternier ${ }^{3,4,5}$, \\ Elisa Amzallag-Bellenger ${ }^{6}$, François Dubos ${ }^{7}$, Françoise Mazingue ${ }^{2}$ and Boualem Sendid ${ }^{{ }^{*}}$
}

\begin{abstract}
Background: The use of isavuconazole is approved for the management of invasive aspergillosis and mucormycosis, only in adults, as no paediatric pharmacology studies have been reported to date. Very few paediatric cases have been published concerning the use of isavuconazole. Amphotericin B is the only antifungal agent recommended in paediatric mucormycosis, but adverse effects and especially nephrotoxicity, even with the liposomal formulation, could be problematic. In this context, the use of other antifungal molecules active on Mucorales becomes needful.

Case presentation: We describe a case of mucormycosis with rapid onset dissemination in a 3-year-old girl recently diagnosed with acute lymphocytic leukaemia. She was successfully treated with isavuconazole alone and then in combination with liposomal amphotericin B. Isavuconazole therapy was guided by therapeutic drug monitoring.

Conclusions: This case offers new perspectives on the potential use of isavuconazole in children with mucormycosis, as an alternative or adjunct to liposomal amphotericin B.
\end{abstract}

Keywords: Isavuconazole, Mucormycosis, Paediatrics, Drug-monitoring, Lichtheimia

\section{Background}

The use of isavuconazole is approved for the management of invasive aspergillosis and mucormycosis, only in adults, as no paediatric pharmacology studies have been reported to date [1]. Very few paediatric cases have been published concerning the use of isavuconazole [2, 3]. Amphotericin $\mathrm{B}$ and posaconazole are the only antifungal molecules recommended in mucormycosis in patients with haematological malignancies [4]. However, posaconazole is not yet approved in paediatric population, and the availability of IV and new per os formulations is recent. Moreover adverse effects, especially nephrotoxicity, related to the use of amphotericin B, liposomal formulation included, could be problematic. In children, therapeutic options are

\footnotetext{
* Correspondence: bsendid@univ-lille2.fr

† Marjorie Cornu and Bénédicte Bruno contributed equally to this work.

${ }^{1}$ Laboratoire de Parasitologie Mycologie, CHU Lille, Univ. Lille, INSERM U995 -

LIRIC - Lille Inflammation Research International Centre, F-59000 Lille, France

Full list of author information is available at the end of the article
}

limited and the use of other antifungal molecules active on Mucorales becomes necessary.

\section{Case presentation}

At the end of 2015, a 3-year-old girl, with B-cell acute lymphocytic leukaemia with TEL-AML1 fusion and profound neutropenia, was started treatment with EORTC 58081 protocol (NCT01185886), medium risk AR1. After 19 days of prednisolone $\left(60 \mathrm{mg} / \mathrm{m}^{2} /\right.$ day $)$, two doses of vincristine $\left(1.5 \mathrm{mg} / \mathrm{m}^{2}\right)$, one dose of daunorubicin $\left(30 \mathrm{mg} / \mathrm{m}^{2}\right)$ and one dose of asparaginase $\left(10,000 \mathrm{IU} / \mathrm{m}^{2}\right)$, she developed febrile neutropenia with digestive problems. Procalcitonin and serum C-reactive protein (CRP) levels were 1.85 $\mathrm{ng} / \mathrm{mL}$ and $91 \mathrm{mg} / \mathrm{L}$, respectively. Chemotherapy was discontinued and antibiotherapy was started with ceftriaxone. Due to persistence of fever, ceftriaxone was switched on Day 3 to piperacillin-tazobactam for 14 days and amikacin for 3 days. At that time, neutrophil count was $0.5 \times 10^{9} / \mathrm{L}$. Increasing CRP $(350 \mathrm{mg} / \mathrm{L})$ prompted the addition of 
caspofungin on Day $6\left(70 \mathrm{mg} / \mathrm{m}^{2}\right.$ day 1 , followed by 50 $\mathrm{mg} / \mathrm{m}^{2} /$ day) following a local protocol established according to international guidelines [5]. Twice weekly screening for serum mannan, galactomannan (Platelia ${ }^{\mathrm{Tw}}$; Bio-Rad Laboratories) and (1,3)- $\beta$-D-glucan (Fungitell ${ }^{\mathrm{rw}}$; Associates of Cape Cod, Inc.) remained negative. On Day 10 of fever, a chest computed tomography (CT) scan showed condensation in the left lower lobe associated with right pleural effusion evocative of invasive aspergillosis. Treatment with intravenous voriconazole was started $(9 \mathrm{mg} / \mathrm{kg}$ bid day 1 , then $8 \mathrm{mg} / \mathrm{kg}$ bid) and caspofungin was stopped. An abdominal ultrasound showed bilateral nephromegaly. Direct microscopic examination, culture, galactomannan detection and Aspergillus q-PCR in bronchoalveolar lavage were negative. All blood cultures remained sterile.

On Day 21 of fever, neutrophil count was $11.2 \times 10^{9} / \mathrm{L}$. Fundoscopy was performed because of a reduction in visual acuity, revealing multiple subretinal foci suspected to be fungal in origin. Direct microscopy of vitreous humour revealed large, aseptate, ribbon-like hyphae. Among the different mycological techniques used, only Mucorales q-PCR was positive for Lichtheimia spp. (Cq 31) in vitreous humour, but was negative in serum. Magnetic resonance imaging (MRI) showed two abscess-like cerebral lesions and confirmed the kidney infiltration (Fig. 1a). A diagnosis of disseminated mucormycosis was established.

Despite limited experience in children, voriconazole was switched to isavuconazole (ISAV) (compassionate off-label use) instead of liposomal amphotericin B (L-AmB), because of renal impairment. Each dose $(70 \mathrm{mg}$ every $8 \mathrm{~h}$ for $48 \mathrm{~h}$, then $70 \mathrm{mg} /$ day IV) was infused over $1 \mathrm{~h}$. Plasma drug monitoring was implemented from Day 3 after ISAV introduction (AISAVI) and was repeated regularly up to Day 150 (Fig. 1a). Considering a target trough plasma level (TPL) of $2000-4000 \mathrm{ng} / \mathrm{mL}$ (approximate average adult TPL observed in Phase 3 studies) [6, 7], low TPL on Day 5 AISAVI prompted an increase in dose to $90 \mathrm{mg} /$ day. A pharmacokinetic profile (Fig. 1b) obtained on Day 7 AISAVI showed that TPL decreased to $1110 \mathrm{ng} / \mathrm{mL}$ at 24 $\mathrm{h}$. The ISAV dosage was changed to $90 \mathrm{mg}$ twice daily and L-AmB $(10 \mathrm{mg} / \mathrm{kg} /$ day $)$ was added despite renal impairment because of the cerebral lesions and difficulties in achieving the ISAV TPL target. The TPL target was reached on Day 17 AISAVI and levels were stable by Day 24. In order to facilitate home nursing care, the route of administration was changed to capsules (100 mg bid). Due to difficulties in swallowing, the capsules were opened and the contents dissolved in an acidic beverage. After 1 week, the mixture was introduced via a nasogastric tube because of vomiting. Median TPL was $4890 \mathrm{ng} / \mathrm{mL}$ from Day 66 AISAVI and remained stable over time, while the maximum concentration was obtained between 1 or $2 \mathrm{~h}$ after administration, with values varying between 4200 and 4690 ng/ml (Fig. 1b).

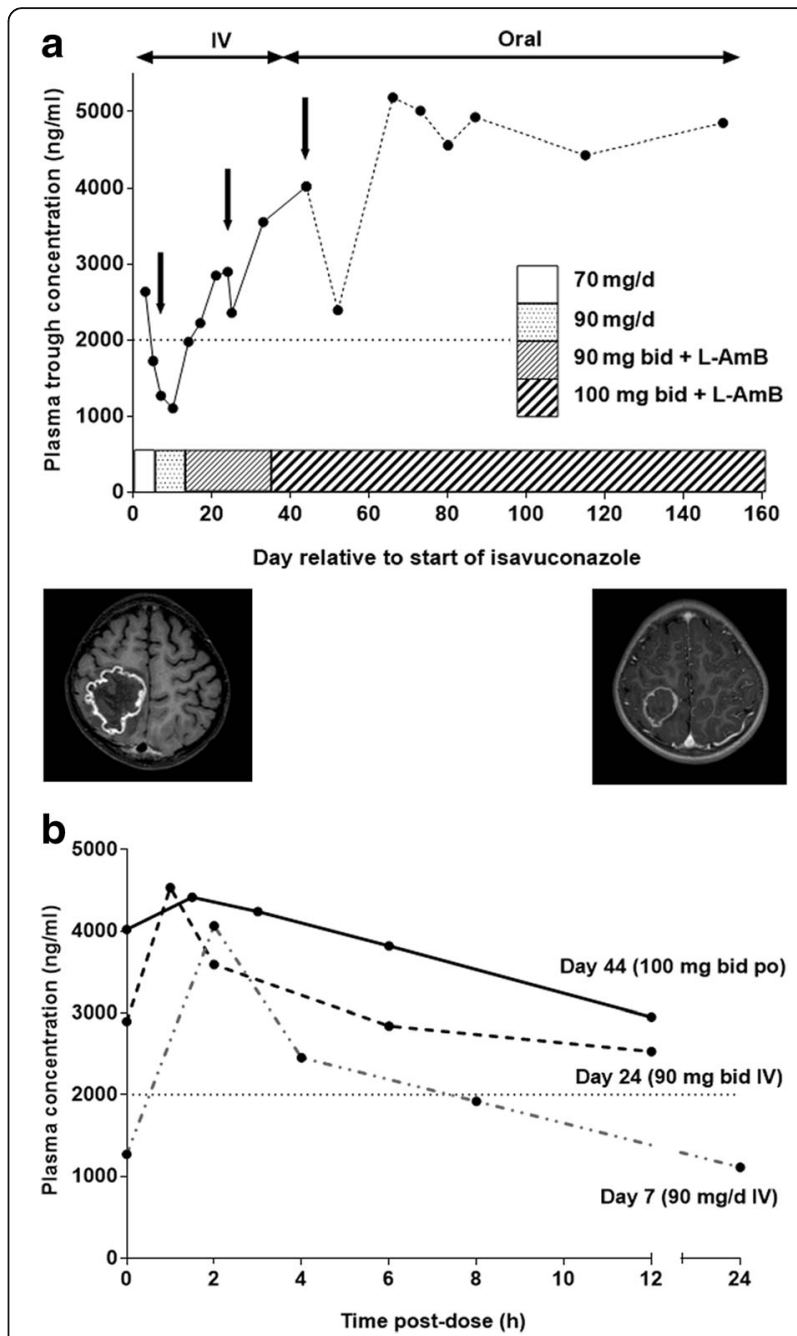

Fig. 1 a Plasma trough concentration of isavuconazole after intravenous (IV) or oral dosing (arrows indicate times of pharmacokinetic study days). In parallel, cerebral MRIs on Day 21 of fever and after 6 months of antifungal treatment showing regression of a ring-enhanced cerebral lesion (from $5.5 \mathrm{~cm}$ in diameter to $3.2 \mathrm{~cm}$ ) in the right frontal parietal region. b Pharmacokinetic profiles of isavuconazole. Plasma concentrations of isavuconazole during $24 \mathrm{~h}$ following dosing at day 7 (90 mg/d, IV), and during $12 \mathrm{~h}$ following dosing day 24 (90 mg bid, IV) and day 44 (100 mg bid, oral). (bid, twice a day; IV, intravenous; L-AmB, liposomal amphotericin B; po, per os)

With the exception of slight nausea/vomiting during the first 2 months after initiation, no adverse effects were noted with ISAV, and liver enzymes were in the range of normal values observed in healthy subjects. The patient was in complete cytological and molecular remission and was chemotherapy-free for 7 months, until her leukaemia relapsed at 8 months. The patient was treated with the first-line CAALL-F01 protocol (NCT02716233), medium risk, and was in complete remission 4 months after relapse. Because of the risk of drug interactions, $\mathrm{L}-\mathrm{AmB}(7 \mathrm{mg} / \mathrm{kg} /$ day $)$ was continued alone for 4 months and was then replaced with ISAV (50 mg twice daily). 
Antifungal treatment was maintained during maintenance chemotherapy. The size of the cerebral abscesses decreased between the first and last MRI (at 16 months) from $55 \times 37$ and $45 \times 38.4 \mathrm{~mm}$ to $23.5 \times 18$ and $17 \times 17 \mathrm{~mm}$ with persistence of hypometabolism on a fluorodeoxyglucose-positron emission tomography scan (FDG PET/CT). Renal insufficiency was stable with clearance of $78 \mathrm{ml} / \mathrm{min} / \mathrm{m}^{2}$ according to the Schwartz formula. The loss of left-sided vision was irreversible. After 24 months of treatment, the patient was still alive without further damage. The treatment timeline is shown in the Table 1.

\section{Discussion and conclusions}

The incidence of mucormycosis in Europe is increasing [8-10]. Haematological malignancy is the prominent underlying disease, accounting for $32-38 \%$ of cases [10]. Diagnosis of mucormycosis depends on a combination of clinical, radiological and mycological criteria, and is often missed or delayed. Our patient was diagnosed 25 days after the onset of fever. The time between the first symptoms and diagnosis ranges from 0 to 30 weeks [11]. In our patient, disseminated mucormycosis appeared as an early complication of leukaemia (19 days after the start of chemotherapy). However, her fungal infection may have begun to develop before the diagnosis of leukaemia, probably in relation to the initial profound neutropenia. She rapidly presented with cerebral, ocular, pulmonary, muscular and renal lesions. Although surgery may improve survival $[12,13]$, the discovery of cerebral and disseminated lesions in this patient prevented surgical intervention. L-AmB is the most effective antifungal agent against Mucorales with doses up to $10 \mathrm{mg} / \mathrm{kg}[12,14]$. More recently, two azoles with potent activity against Mucorales have been developed as alternatives to L-AmB: posaconazole and ISAV $[6,12]$. In animal models, azoles penetrate brain tissue well [15]. However, neither posaconazole nor ISAV drug are currently approved for paediatric use. Only an oral suspension posaconazole has been tested in children and this resulted in high inter- and intra-patient variability in serum concentrations [16]. An intravenous formulation was not available in France at that time. ECIL-6 guidelines recommend posaconazole with grade CIII as an alternative treatment if $\mathrm{AmB}$ formulations are contraindicated [4]. Recently, two trials

Table 1 Timeline of events

\begin{tabular}{|c|c|c|c|c|}
\hline & Clinical features & Biology results & Antimicrobial therapy & \\
\hline D-19 & Start of chemotherapy & Neutropenia & & \\
\hline Do & Febrile neutropenia & High level of CRP and PCT & Antibiotherapy introduction & Ceftriaxone $100 \mathrm{mg} / \mathrm{kg} / \mathrm{d}$ \\
\hline D3 & Persistence of fever & Rising of CRP and PCT rates & Antibiotherapy switch & $\begin{array}{l}\text { Tazobactam Piperacillin } 400 \text { mg/kg/d } \\
\text { Amikacine }\end{array}$ \\
\hline D6 & Persistence of fever & & Adding antifungal therapy & $\begin{array}{l}\text { Caspofungin } 70 \mathrm{mg} / \mathrm{m}^{2} \text { day } 1 \text {, then } \\
50 \mathrm{mg} / \mathrm{m}^{2} / \mathrm{d}\end{array}$ \\
\hline D10 & $\begin{array}{l}\text { Abnormal chest } C T \text { scan } \\
\text { and abdominal ultra-sound }\end{array}$ & & Antifungal combined therapy & $\begin{array}{l}\text { Adding voriconazole } 9 \mathrm{mg} / \mathrm{kg} \text { bid day } 1 \text {, } \\
\text { then } 8 \mathrm{mg} / \mathrm{kg} \text { bid IV }\end{array}$ \\
\hline D16 & & Negative BAL & $\begin{array}{l}\text { Withdrawal Antibiotherapy } \\
\text { and caspofungin }\end{array}$ & \\
\hline D21 & & Positive Fundoscopy & $\begin{array}{l}\text { Voriconazole intravitreal injection } \\
50 \mu \mathrm{g} / \mathrm{ml}\end{array}$ & \\
\hline D24 & $\begin{array}{l}\text { Abnormal brain MRI } \\
\text { Initiation of TDM on D27 }\end{array}$ & & Switch antifungal therapy & $\begin{array}{l}\text { Isavuconazole } 70 \mathrm{mg} \text { every } 8 \mathrm{~h} \text { for } 48 \mathrm{~h} \text {, } \\
\text { then } 70 \mathrm{mg} / \mathrm{d} \text { IV }\end{array}$ \\
\hline D31 & & & & Isavuconazole 90 mg/d IV \\
\hline D37 & & & Antifungal combined therapy & $\begin{array}{l}\text { Isavuconazole } 90 \mathrm{mg} \text { bid IV } \\
\text { L-AmB } 10 \mathrm{mg} / \mathrm{kg} / \mathrm{d}\end{array}$ \\
\hline D39 & Fever resolution & & & \\
\hline D58 & & & & Isavuconazole $100 \mathrm{mg}$ bid p.o \\
\hline D63 & TPL steady state & & & \\
\hline M6 & $\begin{array}{l}\text { Regression of lesions } \\
\text { on imagery }\end{array}$ & & & \\
\hline M8 & Leukaemia relapse & & Withdrawal isavuconazole & L-AmB 7 mg/kg/d \\
\hline $\mathrm{M} 12$ & Complete remission & & Switch antifungal therapy & Isavuconazole $50 \mathrm{mg}$ bid p.o \\
\hline M16 & $\begin{array}{l}\text { Regression of lesions } \\
\text { on imagery }\end{array}$ & & & \\
\hline
\end{tabular}

$B A L$ bronchoalveolar lavage, bid, twice a day, CRP C-Reactive protein, $d$ day, IV intra-venous, L-AmB liposomal amphotericin B, PCT procalcitonin, $p . o$ per os, TDM therapeutic drug monitoring, TPL trough plasma level 
(VITAL, SECURE) have been reported which led to the recent indication, in adults, of ISAV use in cases where L-AmB is inappropriate [17]. In view of the renal impairment in our patient, ISAV was considered as a treatment option [18].

According to a paediatric epidemiological study based on two large international registries of mucormycosis, mortality rates range from 41.3 to $66.6 \%$ in children suffering from malignancies [13]. Although dissemination was one of two significant factors influencing mortality, our patient is still alive 24 months after the diagnosis of mucormycosis. However, an assessment of the specific contribution of ISAV to this favourable outcome remains difficult. Indeed, the early termination of chemotherapy contributing to faster aplasia recovery, the prolonged remission of leukaemia without chemotherapy and the concomitant use of L-AmB at the start of antifungal therapy may all have played an important role in the outcome. However, it should be emphasized that the fungal lesions continued to regress under ISAV alone. Moreover, tolerance of ISAV was good and this case provides interesting information about ISAV pharmacokinetics and alternative routes of administration in the paediatric population.

Recently, the use of ISAV in three young children, between 4.5 and 7 years of age having developed mucormycosis, has been reported $[2,3]$. For two of them, the initial dose of ISAV was lower than that in adult, 80 and $100 \mathrm{mg} /$ day, respectively. The remaining one received the adult dosage $(200 \mathrm{mg} /$ day). In the present case, we started with the recommended dose of $70 \mathrm{mg} /$ day after a loading dose. Because of the absence of data in children, initial estimation of dose was obtained via extrapolation approach based on pharmacokinetic-pharmacodynamic modelling and calculation based on body surface area. Altogether, pharmacokinetics studies obtained from these patients suggest that a lower dosage of ISAV is not appropriate for the management of paediatric patients. Indeed, higher drug clearance rate and shorter half- life of ISAV in children as compared with adults may explain lower trough levels obtained in these three cases [2]. The final dosage for two paediatric cases was $200 \mathrm{mg} /$ day, the 7 -year-old girl received a higher dose increased to $2 \times 200 \mathrm{mg}$ /day. In the three previous cases, while the infection was progressing despite surgery/debridement and lipid formulations of $A m B$, the clinical states improved with the addition of ISAV as salvage therapy. No side effects were reported in all of these paediatric cases, which underline the safety of isavuconazole in this population.

Although more evidence is needed to support its paediatric use, this case offers new perspectives on the use of ISAV. Due to the current lack of an established paediatric dose, therapeutic drug monitoring of ISAV must be performed to guide therapy.

\section{Abbreviations}

AISAVI: After isavuconazole introduction; CRP: C-reactive protein; FDG PET/

$\mathrm{CT}$ : Fluorodeoxyglucose-positron emission tomography scan; ISAV: Isavuconazole; L-AmB: Liposomal amphotericin B; MRI: Magnetic resonance imaging;

TPL: Trough plasma level

\section{Acknowledgements}

Not applicable.

\section{Funding}

This work was supported by internal funding "Fonds d'aide à l'émergence et à l'excellence du CHRU de Lille-Bonus H".

\section{Availability of data and materials \\ Not applicable}

\section{Authors' contributions}

$M C, B B, S L, P N, N F, F L, E A B, F B, F M$ and $B S$ were involved in the patient care and the management of her fungal disease. $M C, B B, S L, F D$ and $B S$ wrote the manuscript. All authors read and approved the final version of the manuscript.

\section{Ethics approval and consent to participate}

Basilea Pharmaceutica International Ltd., provided the medication for compassionate use in the context of a Temporary Authorization for Use which was granted by the French National Agency for Medicines and Health Products Safety. Its authorization has been obtained after a multidisciplinary consultation meeting.

In this context, the parents of the child were informed and gave their consent for compassionate use of isavuconazole.

\section{Consent for publication}

Written informed consent for publication of their clinical details and/or clinical images was obtained from the parent of the patient. A copy of the consent form is available for review by the Editor of this journal.

\section{Competing interests}

The authors declare that they have no competing interests.

\section{Publisher's Note}

Springer Nature remains neutral with regard to jurisdictional claims in published maps and institutional affiliations.

\section{Author details \\ ${ }^{1}$ Laboratoire de Parasitologie Mycologie, CHU Lille, Univ. Lille, INSERM U995 - LIRIC - Lille Inflammation Research International Centre, F-59000 Lille, France. ${ }^{2}$ Service d'Onco-Hématologie Pédiatrique, CHU Lille, F-59000 Lille, France. ${ }^{3}$ Paris Descartes University, Sorbonne Paris Cité, Infectious Diseases Unit, Necker-Enfants Malades University Hospital, AP-HP, Imagine Institute, Paris, France. ${ }^{4}$ Institut Pasteur, Unité de Mycologie Moléculaire, CNRS URA3012, Paris, France. ${ }^{5}$ Institut Pasteur, Centre National de Référence Mycoses Invasives et Antifongiques, Paris, France. ${ }^{6}$ Service de Radio-pédiatrie, $\mathrm{CHU}$ Lille, F-59000 Lille, France. ${ }^{7}$ Service des urgences et maladies infectieuses pédiatriques, CHU Lille et Univ. Lille, F-59000 Lille, France.}

Received: 4 September 2018 Accepted: 21 November 2018 Published online: 06 December 2018

\section{References}

1. Ullmann AJ, Aguado JM, Arikan-Akdagli S, Denning DW, Groll AH, Lagrou K, Lass-Florl C, Lewis RE, Munoz P, Verweij PE et al. Diagnosis and management of Aspergillus diseases: executive summary of the 2017 ESCMID-ECMM-ERS guideline. Clin Microbiol Infect. 2018. https://doi.org/10. 1016/j.cmi.2018.01.002

2. Barg AA, Malkiel S, Bartuv M, Greenberg G, Toren A, Keller N. Successful treatment of invasive mucormycosis with isavuconazole in pediatric patients. Pediatr Blood Cancer. 2018. https://doi.org/10.1002/pbc.27281.

3. Pomorska A, Malecka A, Jaworski R, Radon-Proskura J, Hare RK, Nielsen HV, Andersen LO, Jensen HE, Arendrup MC, Irga-Jaworska N. Isavuconazole in a successful combination treatment of disseminated mucormycosis in a child with acute lymphoblastic leukaemia and generalized haemochromatosis: a 
case report and review of the literature. Mycopathologia. 2018. https://doi. org/10.1007/s1 1046-018-0287-0.

4. Tissot F, Agrawal S, Pagano L, Petrikkos G, Groll AH, Skiada A, Lass-Florl C, Calandra T, Viscoli C, Herbrecht R. ECIL-6 guidelines for the treatment of invasive candidiasis, aspergillosis and mucormycosis in leukemia and hematopoietic stem cell transplant patients. Haematologica. 2017. https:// doi.org/10.3324/haematol.2016.152900.

5. Groll AH, Castagnola E, Cesaro S, Dalle JH, Engelhard D, Hope W, Roilides E, Styczynski J, Warris A, Lehrnbecher T et al. Fourth European conference on infections in Leukaemia (ECIL-4): guidelines for diagnosis, prevention, and treatment of invasive fungal diseases in paediatric patients with cancer or allogeneic haemopoietic stem-cell transplantation. Lancet Oncol. 2014. https://doi.org/10.1016/S1470-2045(14)70017-8.

6. Marty FM, Ostrosky-Zeichner L, Cornely OA, Mullane KM, Perfect JR, Thompson GR, 3rd, Alangaden GJ, Brown JM, Fredricks DN, Heinz WJ et al. Isavuconazole treatment for mucormycosis: a single-arm open-label trial and case-control analysis. Lancet Infect Dis. 2016. https://doi.org/10.1016/ S1473-3099(16)00071-2.

7. Maertens JA, Raad, II, Marr KA, Patterson TF, Kontoyiannis DP, Cornely OA, Bow EJ, Rahav G, Neofytos D, Aoun M et al. Isavuconazole versus voriconazole for primary treatment of invasive mould disease caused by Aspergillus and other filamentous fungi (SECURE): a phase 3, randomisedcontrolled, non-inferiority trial. Lancet. 2016. https://doi.org/10.1016/S01406736(15)01159-9.

8. Bitar D, Van Cauteren D, Lanternier F, Dannaoui E, Che D, Dromer F, Desenclos JC, Lortholary O. Increasing incidence of zygomycosis (mucormycosis), France, 1997-2006. Emerg Infect Dis. 2009. https://doi.org/ 10.3201/eid1509.090334.

9. Skiada A, Pagano L, Groll A, Zimmerli S, Dupont B, Lagrou K, Lass-Florl C, Bouza E, Klimko N, Gaustad P et al. Zygomycosis in Europe: analysis of 230 cases accrued by the registry of the European Confederation of Medical Mycology (ECMM) working group on Zygomycosis between 2005 and 2007. Clin Microbiol Infect. 2011. https://doi.org/10.1111/j.1469-0691.2010.03456.X.

10. Petrikkos G, Skiada A, Drogari-Apiranthitou M. Epidemiology of mucormycosis in Europe. Clin Microbiol Infect. 2014. https://doi.org/10.1111/ 1469-0691.12563.

11. Lanternier F, Dannaoui E, Morizot G, Elie C, Garcia-Hermoso D, Huerre M, Bitar D, Dromer F, Lortholary O, French Mycosis Study G. A global analysis of mucormycosis in France: the RetroZygo study (2005-2007). Clin Infect Dis. 2012. https://doi.org/10.1093/cid/cir880

12. Cornely OA, Arikan-Akdagli S, Dannaoui E, Groll AH, Lagrou K, Chakrabarti A, Lanternier F, Pagano L, Skiada A, Akova M et al. ESCMID and ECMM joint clinical guidelines for the diagnosis and management of mucormycosis 2013. Clin Microbiol Infect. 2014. https://doi.org/10.1111/1469-0691.12371.

13. Pana ZD, Seidel D, Skiada A, Groll AH, Petrikkos G, Cornely OA, Roilides E, Collaborators of Zygomyco.net and/or FungiScope R. Invasive mucormycosis in children: an epidemiologic study in European and nonEuropean countries based on two registries. BMC Infect Dis. 2016. https:// doi.org/10.1186/s12879-016-2005-1.

14. Lanternier F, Poiree S, Elie C, Garcia-Hermoso D, Bakouboula P, Sitbon K, Herbrecht R, Wolff M, Ribaud P, Lortholary $O$ et al. Prospective pilot study of high-dose (10 mg/kg/day) liposomal amphotericin B (L-AMB) for the initial treatment of mucormycosis. J Antimicrob Chemother. 2015. https://doi.org/ 10.1093/jac/dkv236.

15. Felton T, Troke PF, Hope WW. Tissue penetration of antifungal agents. Clin Microbiol Rev. 2014. https://doi.org/10.1128/CMR.00046-13.

16. Jancel T, Shaw PA, Hallahan CW, Kim T, Freeman AF, Holland SM, Penzak SR. Therapeutic drug monitoring of posaconazole oral suspension in paediatric patients younger than 13 years of age: a retrospective analysis and literature review. J Clin Pharm Ther. 2016. https://doi.org/10.1111/jcpt.12483.

17. Ledoux MP, Toussaint E, Denis J, Herbrecht R. New pharmacological opportunities for the treatment of invasive mould diseases. J Antimicrob Chemother. 2017. https://doi.org/10.1093/jac/dkx033.

18. Farmakiotis D, Kontoyiannis DP. Mucormycoses. Infect Dis Clin N Am. 2016 https://doi.org/10.1016/j.idc.2015.10.011.

\section{Ready to submit your research? Choose BMC and benefit from:}

- fast, convenient online submission

- thorough peer review by experienced researchers in your field

- rapid publication on acceptance

- support for research data, including large and complex data types

- gold Open Access which fosters wider collaboration and increased citations

- maximum visibility for your research: over $100 \mathrm{M}$ website views per year

At BMC, research is always in progress.

Learn more biomedcentral.com/submissions 